\title{
REVIEW
}

\section{Law, Psychiatry, and Philosophical Analysis}

\author{
LAW AND Psychiatry: Rethinking The Relationship; by Michael \\ S. Moore. $\dagger$ Cambridge: Cambridge University Press, 1984. Pp. xiv, \\ 527. $\$ 59.50$.
}

\section{Reviewed by David A.J. Richards!}

The field of law and psychiatry is the forensic battleground of lawyers and psychiatrists over legal issues of common professional concern, particularly the criminal responsibility of the clinically imsane and the diminished reponsibility of the neurotic. It is a field of discourse marred by an extravagant rhetoric of claim and counterclaim, overstating or understating the proper weight that legal hability should accord psychiatric disabilities. Michael Moore's Law and Psychiatry is a renuarkable achievenient of interdisciplinary learning, argument, and imagination, for it estabhishes a model of meticulous analysis which brings a new diginty to law and psychiatry as a subject of scholarly research. Moore deploys a style of rigorous philosophical argument which brings a judicious and balanced good sense to all the legal issues he discusses. At the saine time, Moore advances the discussion of how psychiatric and psychoanalytic explanation should be understood nuore generally. On balance, Law and Psychiatry is a inajor contribution not only to law and to psychiatry, but also to our understanding of the power of interdisciplinary legal scliolarship when it holds itself to uncompromising standards of rigor, precision, and clarity of argument.

In order to bring out the innovative dimensions of Moore's achievenient, I will analyze eacl of the four issues which organize the arguinent of the book: (1) the constructive view of the person, (2) insamity, (3) the psychoanalytic tlieory of the unconscious, and (4) the unity of the self.

\section{I}

\section{The Constructive View of the Person}

Moore's constructive theory of the person is that practical reason underties personal responsibility in niorals, and hence criminal responsi-

$\dagger$ Robert Kingsley Professor of Law, University of Southem California.

$\ddagger$ Professor of Law, New York University. A.B. 1966, Harvard University; D. Phil. 1970, Oxford University; J.D. 1971, Harvard University. 
bility in law. Moore builds his argument for the constructive theory of the person by reference to the concept of "explanation of action" in terms of practical reason (ch. 1), argues that legal hability assuines this inodel (ch. 2), and then considers a range of psychiatric attacks on this inodel (ch. 3). The discussion in Chapter 3 sets the agenda of the rest of book, a lengthy discussion of the confusions alleged to underlie various psychiatric and psychoanalytic skepticisıns about legal hability and the law's model of personal responsibility.

By the "explanation of action," Moore refers to the notion that we explain human actions as done for certain reasons. That is, we explain human actions as notivated by the actor's systein of desires and associated ends in view of background factual and other behiefs about the world, technology, and the surrounding environment. The actor is only responsible, Moore persuasively argues, when both the ends and the background behiefs satisfy certain minimal conditions of intelligibility and coherence. It is only in such cases that the actor has the capacity of using practical reason-i.e., connecting ends and ineans in a rational manner.

Moore's account of human behavior by reference to practical reason assnmes, but does not exphicitly address, the justificatory role that such reasons often play in both legal or inoral dehiberation about which a prospective course of conduct is best supported or justified by good reasons for action. ${ }^{1}$ Moore elsewhere atteinpts to offer an objectivist normative ethics based on a realist seinantics, ${ }^{2}$ but Law and Psychiatry does not advance the discussion of these issues. Any such sustained account, Moore suggests, would give central play to the ways in which justificatory reasons nay be offerred to and accepted by a person with the capacity to use such reasons in deliberation and act accordingly. When a person accepts and acts on such reasons, the action in question would, of course, be "explanation of action" in terms of practical reason.

Moore explams the notion of autonoiny in terms of persons' capacity to use practical reason to perform actions to achieve their objectives. Moore disavows, however, a stronger conception of autonony which also wonld include second-order critical capacities to reflect on and change our desires. The presence of these latter capacities "should not be seen as a general presupposition of our law as to what persons are like" (p. 111). Thus, Moore suggests that the language of what people deserve (including criminal responsibility) does not apply only to actions that express a character chosen by the person. For this reason, the stronger

1. For one account of human behavior which is consistent with Moore's general position and is based on a theory of justification other than a theory of rational explanation of one's actions, see D. Richards, A THEORY OF REASONS FOR ACTION (1971).

2. See infra Part $\mathrm{V}$. 
conception of autonomy must be rejected as a necessary condition of responsibility as such. But the stronger conception of autonomy does not require the anomalous result that we are not responsible for actions that are "out of character." The capacity for second-order desires is in place whether the agent exercises that capacity in or out of character, or, indeed, whether the agent exercises that capacity at all. In any case, the capacity may be part of the normal background of imputations of responsibility and just deserts without any necessary requirement that all such actions are choices of one's character.

There is, $\mathrm{m}$ fact, good reason to believe that a more complete philosophical account of the justificatory use of practical reason would give a more central place to such second-order critical capacities than Moore suggests. Practical reason, even on Moore's account, is shown by the ways in which persons act for reasons, advancmg desires im the light of relevant circumstances, and persons have autonomy because they can act in light of such reasons. But the capacity to deliberate about which reasons best justify what conduct implies, concurrently, a background capacity to reflect on and assess our desires as a system or whole $\mathrm{m}$ terms of more coherent ways of securing our aims over-all. How can we reasonably delimit the force of practical reason only to consideration of achieving given ends when it naturally extends as well to reflection on those ends themselves? Surely, a theory of practical reason must find any such sharply drawn line irrationally artificial and self-defeating. We criticize, for example, our desires to smoke, or to overeat, and we shape our conduct, within limits, to give these desires a less dominating place in our lives. Thus, practical reason gives place to such critical capacities, which naturally elaborate the very idea of offerring and acceptimg justification of conduct in terms of good reasons for action. Indeed, this deeper interpretation of justificatory reasons suggests, correlatively, a more appealing conception of autonomy as a substantive moral and legal ideal. ${ }^{3}$ Our law, for example, makes the capacity for practical reason a ground for responsibility because such a requirement limits legal hability to conduct fully expressive of our practical reason, including the responsibility for self reflected in our critical capacities.

If responsibility in law and morals assumes some such conception of practical reason, legal and moral responsibility may either radically contract or expand if psychiatry either contracts or expands our factual picture of the force of practical reason in human life. Moore devotes the bulk of the book's argument to a defense of autonomy and responsibility

3. See Richards, Rights and Autonomy, 92 Ethics 3 (1981). Cf. D. Richards, Toleration aNd the Constitution: A Theory of Religious Liberty, Free SPEech, aNd Constrtutional Privacy (forthcoming, Oxford University Press). 
and a corresponding criticisin of what he takes to be inflated claims in both directions of psychiatry and psychoanalysis.

\section{II}

\section{INSANITY}

Moore's discussion of insanity (chs. 4-6) is a sober and illuminating defense of the concept of inental illness largely against the clains of radical psychiatry (for exaniple, Thoinas Szasz ${ }^{4}$ and political-legal advocates $^{5}$ ) that mental illness is an ideological label for deviance, which should not exculpate from legal hability. The standard arguments of radical psychiatry draw their appeal from a combination of philosophical and ethical arguments. Moore argues that the philosophical argumentthat inental illness is a category mistake, imputing a physical concept, illness, to an incompatible inedium, the mental-is itself critically confused and unpersuasive (ch. 4). He attacks the more weighty ethical arguments (for exaniple, that the concept of mental illness has been wrongly apphed to homosexuals) by offering neutral criteria for mental illness, free of ideological and moralistic bias (ch. 5).

It is a tribute to Moore's philosophical acumen and integrity that he does not try to meet the ethical argument against abuse of the label of mental illness by draining the concept of mental illness of inoral content. Rather, he presents a cogent argument that the concept of illness is, imdeed, a function of values. Under this view, mental illness consists of incapacitating impairments of functions to achieve a range of neutrally specified general goods, things all persons would want or value (e.g., health) as conditions of achieving whatever else they would want. Psychiatrists abusively misapply mental illness, according to Moore, by introducing ideological evaluative criteria (for exainple, heterosexual love) instead of neutral evaluative criteria focusing on all-purpose goods (love, for example, whether heterosexual or homosexual) upon which rational persons could agree. The answer to the problem is not a false distinction between descriptive and evaluative questions, but ethical criticisin of what, in this area, is the proper scope of the evaluative criteria implicit in the concept of illness. ${ }^{6}$

4. See generally T. SZASZ, ThE MANUPACTURE OF MADNESS: A COMPaRATIVE STUDY of THE INQUisition AND THE MENTAL HEALTh MOVEMENT (1970); T. SZASZ, IDEOLOGY AND INSANITY: Essays on the Psychiatric Dehumanization of Man (1970); T. SZASZ, LAW, LIBERTY, AND PSYCHIATRY: AN INQUiRY INTO THE SOCIAL Uses of MENTAL HEALTH Practices (1968); T. SZASZ, Psychiatric Justice (1965); T. SZASZ, The MYTH OF MENTAL IlzNess: Foundations of A Theory of Personal Conduct (1961).

5. See generally B. Braginsky, D. BraginsKy \& K. RING, Methods of MADNEss: The Mental Hospital as a LAST Resort (1969).

6. Under Moore's view, for example, mental illness may consist in incapacitating inability to love and be loved. Moore criticizes the ideological view of mental illness which, for example, 
Moore concludes this part of his argument with an investigation of the inoral grounds for retaining an insanity defense in the criminal law, and with a proposal for a defensible formulation of the terms of the defense-namely, psychotic impairments of practical reason. Such impairments incapacitate the agent, preventing the realistic achievement of any of his ends, whatever those ends are; thus, by Moore's neutral criterion for illness, these impairments are mental illnesses. Unsurprismgly, given Moore's general views that practical reason is the moral condition of criminal responsibility, insanity-understood in terms of psychotic impairments of practical reason-must exculpate from criminal hability. Moore takes as cogent and well defended a position on this question as one can find in the Anglo-American literature. He reminds us of what a post-Hinckley generation conveniently forgets or wants to forget: that the insanity defense, suitably circumscribed, is a necessary condition of the very legitimacy of criminal law as a system of justice in a free society.

These three chapters constitute the best work in this fine book. They significantly advance our understanding both of the philosophical status of mental illness and of the proper form and place of the insanity defense in criminal justice. They would, standing alone, establish Moore's reputation as one of the best legal theorists of our generation.

\section{III}

\section{The Psychoanalytic UnConscious}

Moore's discussion of the Freudian unconscious (chs. 7-10), while longer and inore detailed than many lawyers will find useful or illuminating, provides a general defense of the common legal view that the Freudian unconscious, if it exists, should neither increase nor decrease ordinary attributions of responsibility. The argument here will mainly be of interest to psychiatrists and psychoanalysts, who, Moore argues, fail to have a clear understanding of the nature of psychoanalytic explanation and its relation to explanation of actions in terms of the agent's reasons. To the extent that psychoanalytic assunptions are now part of general intellectual culture, the argument may also advance critical understanding of how these assumptions colmect to traditional attributions of responsibility in law and morals. I assess Moore's argument here im terms of its own frame of reference and theoretical anibitions: does it advance understanding of the ways in which psychoanalytic explanations use the concept of the unconscious?

Moore argues early in the book (ch. 3) and elaborates later (ch. 7)

supposes that homosexual preference as such is a mental illness. Moore's attempt to offer neutral categories tends to prevent bias and bigotry in defining mental illness. 
the theme that there are two distinct senses of the unconscious in psychoanalytic therapy and theory: the pretheoretical unconscious and the unconscious of the theoretical metapsychology. The pretheoretical unconscious is the conception of the unconscious implicit in ordinary language and thouglit. The theoretical unconscious is, in contrast, the Freudian dynamic metapsycholology of id, ego, and superego.

Moore's account of the pretheoretical unconscious rests on a problematic picture of the way in which we use "conscious/unconscious" in ordinary speecl (pp. 126-129). We are, Moore argues, "conscious of" our own mental states, of which we liave nonobservational knowledge. We are also, through observational knowledge, "conscious that" events are happening, e.g., that prices are rising. The former sense of nonobservational knowledge has a corresponding sense of "unconscious of," namely, of those of our mental states (for example, memories) to which we are not currently attending. Freud's pretheoretical sense of the unconscious elaborates this ordinary language conception: psychoanalytic procedures, such as free association, enable us to retrieve repressed inemories and other information.

However, Moore's description is insufficient even as an account of ordinary language. First, for example, we may be "conscious of" another's mood of anger only observationally, which suggests that the language of consciousness will not bear the dichotomous distinction ("conscious of" vs. "conscious that") Moore places on it. Second, ordinary, non-Freudian memories, of which we currently are "not conscious," are not, therefore, idiomatically spoken of as "unconscious," any more than actions which are "not voluntary" are, therefore, "involuntary." The ordinary language and thought of "unconscious" play a much more specialized role than Moore imagines, a fact reflected in the way in which unconsciousness in law is limited to quite extre1ne situations of plysical disability, not to ordinary inadvertence.

But the Freudian pretheoretical unconscious is not, in this ordinary language sense, not conscious. Freudian memories, for example, are not accessible to ordinary procedures of more careful attention in the way non-Freudian memories are. They are accessible to current consciousness, if at all, only through special therapeutic procedures. Even then, on one reading of the mature Freud, such memories may not be accessible to consciousness, though the therapist offers a valid psyclioanalytic explanation of the patient's conduct in terms of such memories. ${ }^{7}$ If so, it may be correct to distinguish not two senses of unconscious (the ordinary language/pretheoretical unconscious and the metapsychological uncon-

7. See generally A. GruÜnbaum, The Foundations of Psychoanalysis: A Philosophical Critique 26 (1984). 
scious), but at least three: the ordinary language, the pretheoretical, and the metapsychological.

Moore's insistence on a unitary sense of unconscious, governing both ordinary language and Freudian extended ineinory, is rather paradoxical in view of his later argument about the nature of psychoanalytic explanation in terms of the unconscious (ch. 8). There, Moore argues that many kinds of psychoanalytic explanations are not well understood through the model of motivational explanations in terms of the agent's reasons. If this were true, that truth would be inore naturally explained by a sharper distinction than Moore allows between actors' capacity to retrieve their reasons for action in the "explanation of action" and their incapacity comparably to retrieve psychoanalytic explanations of their actions.

Moore uses his distinction between practical reason in "the explanation of action" and psychoanalytic explanation to fruitful effect in his illuminating discussions of why psychoanalytic explanations, if true, do not significantly increase (ch. 9) or decrease (ch. 10) the proper scope of imputations of responsibility in law or morals. It is as much a mistake, Moore argues, to extend ordinary conceptions of responsibility to unconscious inotives based on Freudian metapsychology as it is to suppose that such unconscious forces must diminish the just scope of attribution of responsibility.

The imputation of responsibility to Freudian forces generally, Moore shows, is based on an undefended and indefensible expansion of ordinary concepts of intentionality to include certain explanatory factors (for example, unconscious rage against one's father). In effect, the insistence that any valid explanation of human conduct must be interpreted on the intentionality model fails to take seriously what may be most innovative and important im psychoanalytic explanation, nainely, that certain motivational forces in us are not things we intend $m$ any intelligible sense of "intend," nor do they play any intelligible role in our "intentions" or our "intentionality." Under Moore's judicious criticism, this insistence appears to be based on a philosophical dogma, which we have no good reason to accept im general.

Moore employs a comparable style of philosophical argument in attacking the claim that Freudian motives must diminish the just scope of responsibility attributions. Moore recently has shown ${ }^{8}$ that the causal truth of Freudian explanation is no more incompatible with normal responsibility attribution than any other causal explanation as such. A more special kind of showing would be required to justify, for example, a claim that unconscious mental states negate the imtentional nature of

8. See Moore, Causation and the Excuses, 73 CALIF. L. REv. 1091 (1985). 
action or the agent's rationality, or to show that an action is compelled. But since this showing cannot be sustamed for all forms of true psychoanalytic explanations, such explanations do not, in principle, undermine ordinary responsibility attributions.

\section{IV}

\section{THE UNITY OF THE SELF}

Moore concludes with a defense of the unity of the self against what he takes to be the dissolution of personal identity by Freudian metapsychology into psychiatric subagents warring amongst themselves (id, ego, and superego) (ch. 11). The general truths of psychoanalytic explanation (conflicts within the self and unconscious motives, for example) do not, Moore argues, require such a radical dissolution of personal identity. Indeed, they are best explained within the framework of the ordinary conception of personal autonomy which Moore defends in Law and Psychiatry.

Freudian metapsychology, however, may be consistent with Moore's notion of the unity of the self if one construes Freud not as a philosopher of the self, but as an empirical psychologist who discovered, in the course of the development of psychoanalytic therapy, iunportant synchromic and diachronic truths of the human psyche long known in myth and biterature. Synchromically, persons experience diverse ego states (being sometimes a parent, sometimes a child) whose natures are clarified in the free association and other techniques of psychoanalytic therapy. Diachronically, these ego states connect in important ways to repressed childhood memories, which may explain our susceptibility to diverse ego states. If these are the essential psychoanalytic discoveries, they do not assume diverse selves in one body, but one self that experiences diverse, often puzzling, and self-consciously alien ego states, and sometimes associated neurotic symptoms. The very premise of psychoanalytic therapy is the person's self-critical sense of conflict and the desire to resolve such conflict. This model assumes the kind of secondorder capacities which, I earhier suggested, are fundanental to the unity of self. If so, Moore may have misconstrued Freud's metapsychology by mischaracterizing a suggestive, highly tentative way of understanding the synchronic and diachromic truths of psychoanalysis. Freud inay have in fact assumed a model of personal integrity, not a philosophical theory of personal nomidentity.

\section{MOORE'S REALISM}

Moore assumes throughout Law and Psychiatry and defends else- 
where ${ }^{9}$ a realist semantics both in legal and moral philosophy. Under realist semantics, tlie essential meaning of legal and moral concepts lies in their descriptive referents. That is, predicates in science identify what tlieir real entities are. For example, realist semantics construes "water" as essentially referring to a natural entity in the world, namely, water. Science is a progressive development of better theories to describe the nature of the natural entity, water, referred to by "water." Correspondingly, legal and moral concepts are, for Moore, essentially referential to some objective legal and inoral property, and better legal and moral theories are better because they more accurately describe the internal structure of the legal and moral property referred to.

Moore's realism is not simply the claim that legal and moral propositions are susceptible of truth values. A moral theory may, for example, attribute truth values to moral propositions through some naturalistic theory of ethics, rather than through a realist reference to a property. ${ }^{10}$ In legal and moral philosophy, there may be good methodological reasons to resist the temptation to interpret one's behefs in the terms of the truth value or validity of legal and moral propositions in the way urged by Moore. Moral philosophy has made great strides recently because it has abandoned the sharp distimction between metaethics (the meaning of ethical concepts) and normative ethics (the application of such concepts to ongoing normative debates). ${ }^{11}$ Moore's realism reintroduces such a dichotomous distinction between the property referred to (meaning) and our theories of such properties (application).

We can, I behieve, say everything Moore wants us to be able to say im moral and legal philosophy without a realist semantics. Sucli a semantics may reasonably tempt us in science, ${ }^{12}$ but in law and ethics, the sense of legal and moral propositions is itself dependent on internally complex concepts of equality. To regard such concepts as themselves approximations of some other property introduces an unneeded and distorting realist epicyle. It wrongly suggests that a moral concept, like good, is essentially a kind of property in the world, like yellow. But that way of understanding inoral semantics was G.E. Moore's unfortunate intuition-

9. See Moore, Moral Reality, 1982 WIs. L. REv. 1061 (1982); Moore, The Semantics of Judging, 54 S. CAL. L. REv. 151 (1981).

10. See, e.g., D. RICHARDS, supra note 1.

11. I have in mind such diverse inoral philosophers as R.M. Hare and John Rawls. See generally R.M. HARE, THE LANGUAGE OF MORALS (1964); R.M. HARE, FreEDOM AND REASON (1963); R.M. Hare, Moral Thinking: Its LeVels, Methods, ANd Points (1981); J. RaWls, A THEORY OF JUSTICE (1971). Hare's theory is neither cognitivist nor naturalistic, though he does explain the validity of some moral reasons and the invalidity of others. Rawls's theory is both cognitivist and naturalistic.

12. For some reasons to resist the temptation, see L. LAUdAN, Science and Values: The Aims of Science AND Their Role in Scientific Debate 102-37 (1984). 
ist legacy to moral philosophy ${ }^{13}$ from which recent moral philosophers liave so profitably freed us and themselves. The gain, I believe, has been a deeper understanding of how moral concepts conceptually connect, in complex ways, not to the world or properties therem, but to our interests, as persons, suitably understood. ${ }^{14}$ Moore's realist semantics from this perspective intellectually regressive.

Moore's attachment to this realist semantics stems from the idea that such realism aloue frees critical intelligence from ordinary language conceptions, tainted as they may be by the science or ethics of the stone age. Suppose ancient Babylonians believed, as they did, that the inorning star and the evening star were different stars. On Moore's view, it would follow, given ordinary language Babyloman conceptions, that Babylonian astronomy could not discover that the stars in question were the same. ${ }^{15}$ A realist semantics would, on the contrary, always leave it a semantic open question whether the stars were the same, and thus not trammel scientific advance. But Moore's case is unpersuasive. Conventional attitudes have often trammelled both scientific and ethical advance, but the problem has not been posed by a tainted semantics but by background factual and normative behiefs. In the Babyloman case, the retarding factor would be the factual behef that the two stars are different, not the background semantics, which would yield to any change in these factual behiefs. Semantics and background behiefs do not covary, as Moore's argument assumes; semantic conceptions may remain stable through widely varying changes in factual and otlier beliefs. A critical perspective botl in scientic and ethics needs not a realist semantics but a critical understanding of the bases for background factual and normative beliefs, and of the ways in which the application of semantic conceptions is sensitive to such beliefs.

\section{VI \\ SOME FURTHER OBSERVATIONS}

Moore's achievement is, I believe, nothing less than the reconstruction of law and psychiatry as an interdisciplinary field of practical and theoretical activity. His conclusion (pp. 416-425) calls for a philosophical rethinking of law and psychiatry to clarify the common ground of principle that unites lawyers witli psychiatrists and psyclioanalysts. The gain, as the book clearly shows, would be not only an understanding of how the factual msights of psychiatry and psychoanalysis should bear

13. See, e.g., G.E. MoORE, Principia ETHiCA (1966).

14. See Richards, Prescriptivism, Constructivism, and Rights, in HaRe and Hounds (D. Seanor \& N. Fotion eds., forthcoming).

15. The example appears in M. Moore, Mind, Brain and Unconscious 50 (unpublished manuscript on file with California Law Review). 
upon the moral questions central to legal discourse, but a deeper understanding of the very structure of psychoanalytic and psychiatric explanation.

The broader importance of this book to law is, I beheve, its challenge to the way in which a learned profession should conceive the role of legal theory im its self-conception. For Moore, legal theory is a remarkable opportunity for interdisciplinary scholarship that asks deeper philosophical questions both about law and the fields on which law inevitably abuts. Moore's achievement is that he gives us the best possible nodel for how this opportunity nay be seized, making legal theory one with a larger umiversity conception of scholarship and reaching out beyond even the umiversity imto the life of the mind itself. There is no stridency here, no sterile self-promotion, no confusion of academic prestige with good argument, no debaseinent of academic standards. There is simply the quiet voice of a reasonable person working through problenis and subjecting himself, as the humility of learning requires, to the highest standards of good argument observed anywhere today. If legal theory is to find its useful place in the life of the mind, it will be through work pitched at this level of ambition, integrity, and performance. 